\title{
Article \\ Defending Victims, Practicing Restraint: God-Consciousness and the Use of Force in the Qur'an
}

\author{
John J. Ranieri
}

Citation: Ranieri, John J. 2022. Defending Victims, Practicing Restraint: God-Consciousness and the Use of Force in the Qur'an. Religions 13: 124. https://doi.org/ 10.3390/rel13020124

Academic Editors: Ephraim Meir, Ed Noort, Louise du Toit and Wolfgang Palaver

Received: 29 December 2021

Accepted: 20 January 2022

Published: 27 January 2022

Publisher's Note: MDPI stays neutral with regard to jurisdictional claims in published maps and institutional affiliations.

Copyright: (C) 2022 by the author. Licensee MDPI, Basel, Switzerland. This article is an open access article distributed under the terms and conditions of the Creative Commons Attribution (CC BY) license (https:// creativecommons.org/licenses/by/ $4.0 /)$.
Department of Philosophy, Seton Hall University, South Orange, NJ 07079, USA; john.ranieri@shu.edu

\begin{abstract}
The Qur'an speaks frequently of victims and the need to defend them-whether they are the marginalized, the oppressed, those who bring God's word to a resistant people, or the early community of believers. However, the obligation to defend victims leads to the question of whether force can be used in their defense (including self-defense). Too often, this question is addressed by isolating passages that allow for the use of force, trying to identify their occasions of revelation, and considering whether later passages abrogate earlier ones. This approach suggests that the use of force or violence is an identifiable theme in the Qur'an, detachable from its broader message. However, the question of how and when force may be used is inseparable from the important Qur'anic notion of God-consciousness (taqwa), which ifs presupposed in the Qur'an when considering whether the use of force is justified. God-consciousness serves both as a source of restraint for those who would resort to violence out of anger or indignation, as well as a critical standard for those who find themselves conflicted over the possible use of force. Considering the question of the use of force in the defense of victims in light of God-consciousness shifts the focus away from isolated passages and arguments about abrogation to a more open and adaptable approach that calls into question the use of force as one option among others, and leaves open up the possibility of a non-violent response as entirely keeping with the spirit of the Qur'an.
\end{abstract}

Keywords: Qur'an; violence; God-consciousness

\section{Defender of Victims}

The Qur'an consistently and emphatically sides with the marginalized, the indigent, and the oppressed. ${ }^{1}$ The "alms tax is only for the poor and the needy ... for freeing slaves, and for those in debt, for God's cause, and for needy travelers. This is an obligation from God" (9:60). ${ }^{2}$ The reference to bondage in this passage can also be understood to include "all those forms of subjugation and exploitation-social, economic or political-which can rightly be described as 'slavery'". ${ }^{3}$ In the case of the actual institution of slavery, the Qur'an tolerates the practice, while qualifying it in ways which mitigate its harshness and point toward its eventual abolition. ${ }^{4}$ Typical of the Qur'anic sense of obligation in this regard is the following:

[The truly virtuous are] those who fulfill their vows, and fear a day of sweeping horror, and give food-despite their desire for it-to the poor, the orphan, and the captive, saying to themselves, "We feed you only for the sake of God, seeking neither reward nor thanks from you. We fear from our Lord a horribly distressful Day. (76:8-9)

Muhammad Asad observes how the meaning of "to give food" in this instance "comprises every kind of help and care, both material and moral". ${ }^{5}$ Likewise, both Asad and Yusuf Ali broaden the notion of "captive" to include all those "who have no mental or moral resources, or have no one to look after them or are held down in social or moral or economic captivity". Help is to be extended to all who are held "captive" in any sense, regardless of whether they are believers or unbelievers. ${ }^{6}$ 
While the Qur'an expresses a general concern for the vulnerable within society, there are specific groups which are the object of particular solicitude. Among these are the poor and orphans. Attending to the needs of the poor is mandatory, and obligatory almsgiving in the form of a tax (zakah), as well as charity which exceeds that required by this communal obligation, are enjoined on all believers. The spoils taken from those who fight the believers are intended to serve the needs of the community as a whole, with special attention to the needs of the indigent. The sacrifices offered during pilgrimage may be eaten by the pilgrims themselves, but they are intended primarily for the sustenance of the poor. ${ }^{7}$ Neglect of one's duties toward the poor is criticized and is considered to be as serious as the neglect of prayer. What is made abundantly clear in all these passages is God's concern for those in society who are powerless, whose situation is precarious, and who are defenseless. Attending to the needs of such people and defending them from exploitation is a constitutive element of one's service to God, and those who do so freely and conscientiously are doing God's will.

A particular form of victimization of the defenseless that is denounced in the Qur'an is the pre-Islamic Arabian practice of female infanticide. ${ }^{8}$ In what is likely the first mention of this practice in the text, the seriousness with which God views the killing of one's offspring is made apparent by its inclusion among the eschatological signs of the Last Day:

When the sun is put out, and when the stars fall down; and when the mountains are blown away ... and when the seas are set on fire ... and when baby girls, buried alive are asked for what crime they were put to death, and when the records of deeds are laid open, and when the sky is stripped away, and when the Hellfire is fiercely flared up, and when Paradise is brought near-on that Day each soul will know what deeds it has brought along. (81:1-3, 8-14)

Another notable passage dealing with infanticide occurs in Surah 6: "Likewise, the pagans' evil associates have made it appealing to them to kill their own children-only leading to their destruction as well as confusion in their faith" (6:137). Muhammad Asad observes how the verse is meant primarily to call attention to the killing of infant girls, but that it also includes the less common practice of the ritual sacrifice of boys. ${ }^{9}$ The Study Quran mentions how "Although the verses specifically reproach those who engaged in this practice [female infanticide], they can also be read as indicating that all who have been wronged in this world will have the opportunity to demand justice of their oppressors and be vindicated in this life or the next" ${ }^{10}$ The murder of children may be a particularly heinous manifestation of the victimization of the innocent, but in decrying the slaying of infants, the Qur'an makes clear how, in all circumstances, God takes the side of the voiceless.

Perhaps the most frequently recurring form of victimization described in the Quran is the persecution of prophets and believers. There are close to one hundred and twenty references to the persecution of God's messengers and prophets, with a sizeable number of additional passages addressed more directly to suffering believers and to the prophet. These two kinds of references are deeply intertwined; more often than not, the descriptions of the plight of earlier messengers is meant to encourage the early community of believers and the prophet Muhammad himself to be patient and to trust in God in the face of oppression. ${ }^{11}$ Every community receives a prophet calling the people to acknowledge God, and the Qur'an recounts many instances of peoples and individuals who reject both the message and the messengers: "the people of Noah denied the truth, as did other enemy forces afterwards. Every community plotted against its prophet to seize him" (40:5). In some instances, this hostility takes the form of the slaying of prophets by the people to whom they are sent, "rejecting some and killing others" (2:87). The prophets are sent to warn an ungrateful humanity. While the accounts of their activities are often described as punishment stories, they can, with equal justification, be understood as stories of collective persecution and expulsion, in which God never fails to take the side of the persecuted prophet, who serves as a model and source of hope for the beleaguered believer.

The story of the prophet Moses is paradigmatic; themes of victimization, oppression, and liberation are prominent. ${ }^{12}$ God's response to their oppression is to rescue the Israelites 
from the violence with which they are threatened: "And We certainly delivered the children of Israel from the humiliating torment of Pharaoh. He was truly a tyrant, a transgressor" (44:30). The frequency with which this intervention by God is recounted within the text attests to the Qur'an's concern for all who are oppressed. ${ }^{13}$ Given the universalism of the Qur'an's message, the liberation of the Israelites from bondage is a topos representing God's siding with all of history's victims.

Farid Esack finds in the Qur'anic accounts of Moses and the liberation of the Israelites from bondage a "preferential option for the oppressed": "[Mustad'af] refers to someone who is oppressed or deemed weak and of no consequence and is treated in an arrogant fashion. The mustad'afun are thus those people of 'inferior' social status who are vulnerable, marginalized or oppressed in the socio-economic sense". He further distinguishes between the terms used in the Qur'an to describe the poor, marginalized, and indigent on the one hand, and the mustad'afun: "The major difference in the term mustad'afun is that someone else is responsible for their condition. One can only be mustad'afun as a consequence of the behavior or policies of the arrogant and powerful". In the Qur'an "a preferential option for the mustad'afun is made in unambiguous terms". This preferential option "is reflected the particularized identification of God Himself with the oppressed, the lifestyles and methodology of all the Abrahamic prophets, the Qur'anic denunciation of the powerful and the accumulation of wealth, and the Qur'an's message of liberation to women and slaves". ${ }^{14}$ The Qur'an repeatedly stresses the gratuitous goodness of God in rescuing and sustaining the Israelites. ${ }^{15}$ The liberation of Israel from oppression is a paradigmatic exemplar of the universality of God's concern for victims. ${ }^{16}$

The stories of the prophets are intended to offer encouragement and support to Muhammad and his followers, the early community of believers, who would eventually come to identify themselves as Muslims. ${ }^{17}$ This is an important point because it underscores how, at its beginning, the Muslim community was a persecuted minority. The prophet is reminded how "Indeed, messengers before you were rejected but patiently endured rejection and persecution until Our help came to them. And God's promise to help is never broken" (6:34). ${ }^{18} \mathrm{He}$ and his disciples are hated for no other reason than believing in God (60:1; 85:8). They will be tested by hunger, loss of possessions, expulsion from their homes, and even death, but through patient perseverance and faith in God they will eventually prevail. ${ }^{19}$ As was the case with so many of the prophets, their foes may scheme against the believers, but those persecuted will be heard and answered by God: "Remember when you were vastly outnumbered and oppressed in the land, constantly in fear of attacks by your enemy, then He sheltered you, strengthened you with His help, and provided you with good things so perhaps you would be thankful" (8:26). Those rescued by God are not to simply rejoice in their deliverance; they are called upon to cooperate with God in the pursuit of justice and the relieving of oppression. They are never to forget their rescuer and sustainer: "Who responds to the distressed when they cry to Him, relieving their affliction, and Who makes you successors in the earth? Is it another god besides God? Yet you are hardly mindful!" (27:62).

\section{In God's Cause}

The question of human responsibility in bringing about the kind of world God desires compels all those who would raise it to consider what actions are acceptable in order to faithfully bear witness to the sustainer and defender of victims. Furthermore, this necessarily leads to further reflection as to what may be done in order to defend victims, whether in cases of self-defense or intervention on behalf of others. To raise such questions is to contemplate the possibility of the legitimate employment of violence in defense of victims. The Qur'an does not treat violence as a separate theme; it is not interested as much in the nature of violence as in its effects. "Working corruption on earth" is frequently decried in the text, and the phrase often refers to violence and disorder. ${ }^{20}$ Violence in the Qur'an is usually discussed in relationship to oppression-both as the cause of this evil and as a response to it. To put this within some context (and to try to dispel the notion 
that jihad is the central focus of the Qur'an's teaching on the use of force) consider how there are 319 references to oppression in the Qur'an, 173 verses that refer to fighting against injustice and oppression, and 106 examples of enemies attacking without provocation and/or transgressing the limits of what is permitted with regard to accepted standards concerning the use of force. By contrast, "to wage war" occurs six times, retaliation six times, and jihad four times. ${ }^{21}$ For the Qur'an, the world is not as God intended it to be, so questions about the use of violence revolve around how best to respond to the injustice being committed against the innocent, and considerations of when and how it may be used to establish a just social order. Mohammed Arkoun writes: "The designations of the forms of 'violence' are never named as such but are always aiming at an attitude, or at intolerable conduct that rejects values, knowledge, and the 'limits' fixed by God and his envoy. The processes of composition and the arguments of qur'anic discourse strive to instill the idea of a legitimate 'violence,' humanized in the sense of 'making sacred the human individual' (tahrim al-nafs), and to protect him from arbitrary domination, or pointless killing in the pursuit of mere power, booty, and conquest of territory, etc.". 22 This is an important point, which aptly summarizes the Qur'an's attitude toward the use of violence. It underlines how sacredness applies to persons being defended, and not to the violence used to defend them. ${ }^{23}$ Violence in the Qur'an may be tolerated, and under certain conditions, even mandated; however, it is not considered sacred in itself. It is easy then, to understand the tensions which run through the Qur'an with regard to the use of violence, since it is simultaneously condemned when in the service of oppression, accepted (within limits) in order to liberate the afflicted, and carefully scrutinized so as not to be guilty of "exceeding all bounds".

Before entering into a discussion of these issues and how the Qur'anic idea of taqwa functions in relation to the use of force, a word needs to be said with regard to questions which arise when interpreting the Qur'an's teaching about violence. Given the generally accepted division of surahs into Meccan and Medinan, the references to violence in the Qur'an have tended to be understood diachronically. In this view, there is a movement from an attitude of patient endurance in the face of persecution to a stance in which force is justified in self-defense and in the interest of protecting the oppressed. Many traditional Muslim commentators have then applied the principle of abrogation to these texts, arguing that the later Medinan references abrogate those from the earlier Meccan period. The result of this interpretive strategy is to allow these later texts which permit or even command the use of violence to acquire normative status, while the earlier texts which counsel patience and forbearance are marginalized. However, there are scholars, who, while accepting the traditional Meccan-Medinan periodization with regard to the use of force in the Qur'an, do not necessarily accept the idea of abrogation. Rather than viewing the earlier, more pacific attitudes as having been abrogated, they argue that the changes within the teaching are to be explained by the shifting circumstances confronting Muhammad and his followers. Thus, the acceptance of the use of force is not seen as a universally binding doctrine superseding previous understandings, but as a response to specific situations in which the newly founded community struggles to maintain its existence and to order society in accordance with divine justice. In this interpretation, the option for non-violent solutions remains possible. This understanding is characteristic of those who read these texts synchronically. Rather than mapping them diachronically based upon the life of the prophet and his community, the diverse views on the use of force can be understood as expressing the multiple perspectives being debated simultaneously among the believers. ${ }^{24}$ Diachronic and synchronic interpretations are not mutually exclusive; evolutionary views can allow for a multiplicity of perspectives at any given stage of the evolution of the teaching on the use of force, while synchronic explanations do not preclude development over time in which some of the contested views come to eventually dominate the thinking of the community (while not necessarily invalidating the other ideas present in the milieu of the time). Whether one subscribes to a diachronic or to a synchronic understanding, it is 
clear that there are multiple voices present in the Qur'an which address the question of whether, when, and how force may be employed.

Another issue which affects the manner in which the Qur'an's statements on violence and fighting are to understood is terminological, as agreement is often lacking regarding the meaning of terms such as "religion", "sacred", and "holy", as well as the meaning of the distinction between the "religious" and the "secular". This confusion and lack of agreement bedevils the discussions surrounding these questions. How else is it possible to explain the strikingly different assessments as to whether jihad or warfare are rightly described as "holy war"? The answer to this question hinges almost entirely on the definition of "holy war" being used, and these definitions vary widely. Used in this way, the term jihad is distorted through a misunderstanding of its broader meaning: "[The] simple use of jihad as a way of describing what Muslims believe about conquest, conversion, and violence is worse than meaningless in an intellectual and cultural environment in which specifics regarding such questions need to be spelled out with the utmost precision and care, rather than masked under catchall terms ..." ". The term jihad is more accurately rendered as "striving or struggling in the path of God" and it has a far broader meaning than simply "war". There can be forms of striving against injustice which could be accurately described as jihad, but which do not involve the use of force. It is also important to distinguish between "war" (harb) and "fighting" (qital) in the Qur'an. ${ }^{25}$ In addition, care must be taken not to read into the Qur'an later developments in Islamic tradition, in which Muslim legal scholars make use of Qur'anic verses in order to justify the territorial expansion of Islam. To define holy war as one which is undertaken "by providing religious justification", without a clear and agreed-upon understanding of "religion", would seem to beg the question. Further problems arise when there are commentators who attribute to the Qur'an the view that warfare is sacred, while others deny this emphatically. ${ }^{26}$ Given the limited scope of this essay, these problems cannot be resolved here; however, it is important to at least identify where the tensions lie before discussing specific verses in the text.

Within the Qur'an, there can be found a range of sayings, instructions, admonitions, and exhortations with regard to the use of force in response to injustice and oppression. Addressed to the community of believers during times of trial, several verses advocate patient forbearance in the face of persecution: "O believers! Patiently endure, persevere, stand on guard, and be mindful of God, so you may be successful" (3:200). The community is encouraged to follow the way of patient forbearance, secure in the knowledge that God supports them: "As for those who emigrated in the cause of God after being persecuted, We will surely bless them with a good home in this world...It is they who have patiently endured, and in their Lord they put their trust" (16:41-42). According to some interpreters, the early followers of Muhammad, during their time in Mecca, were forbidden to retaliate with violence against their persecutors. ${ }^{27}$ Fortunate and faithful servants are those who bear wrongs patiently and who repay evil with good: "And they are those who endure patiently, seeking their Lord's pleasure, establish prayer, donate from what We have provided for them-secretly and openly-and respond to evil with good. It is they who will have the ultimate abode" and "Good and evil cannot be equal. Respond to evil with what is best, then the one you are in a feud with will be like a close friend. But this cannot be attained except by those who are patient and who are truly fortunate" (13:22; 41:34-35). ${ }^{28}$

Even when a right to retaliation is acknowledged, the way of reconciliation and forgiveness is recommended as the better response. Asad translates 42:40 in a way which suggests an awareness of the dangers of escalation in situations where retaliation is chosen: "But [remember that an attempt at] requiting evil may, too, become an evil: hence, whoever pardons [his foe] and makes peace, his reward rests with God ... ". Likewise, Sachedina repeatedly emphasizes how cautious the Qur'an is with regard to the use of violence, and he reminds his readers how retaliation may be permitted, but it is never commanded. ${ }^{29}$ We find a similar exhortation in 16:125-27: "Invite all to the way of your Lord with wisdom and kind advice, and only debate with them in the best manner ... If you retaliate, then let it be equivalent to what you have suffered. But if you patiently endure, it is certainly best 
for those who are patient. Be patient O Prophet, for your patience is only with God's help". Firestone takes verses 126 and 127 dealing with retaliation to have been revealed on the occasion of the aftermath of the Battle of Uhud ( $625 \mathrm{CE})$, where, according to tradition, the believers (including Muhammad) were incensed at the mutilation inflicted on the bodies of their warriors by their enemies. Wishing to retaliate savagely, these verses were revealed, arguing for restraint and a proportionate response. In this interpretation, verse 125, urging reasonable debate with their opponents, should be understood as separable from the two following verses (since it does not refer to physical violence), and as representative of an earlier, non-violent approach to dealing with conflict between the community of believers and those who rejected their message. Firestone argues further that, rather than having been abrogated by later verses, the approach advocated in verse 125 has simply been ignored. Asad, however, understands verses 126 and 127 as an expansion of the message presented in the previous verse, and he translates the passage in a way which reflects this view: "Hence, if you have to respond to an attack [in argument], respond only to the extent of the attack leveled against you; but to bear yourselves with patience is indeed far better for [you, since God is with] those who are patient in adversity. Endure, then, with patience [all that they who deny the truth may say]-always remembering that it is none but God who gives you the strength to endure adversity". For Asad, these verses affirm both a commitment to rational debate in matters of religion and an embrace of the injunction of 2:256, forbidding coercion in matters of faith. In his view "believers are admonished to observe self-restraint while arguing with people of another persuasion, and never to offend against decency and intellectual equity. Although retaliation in argument is permissible if one's integrity is impeached by an opponent, the sequence makes it clear that it is morally preferable to renounce it altogether and to bear the unjust attack with patience". While acknowledging that a more aggressive, militaristic stance came to predominate in Islam, and without claiming that the early community was committed to pacifism, these scholars and others like them argue that the more pacific, long-suffering posture advocated in these Qur'anic verses never disappeared, and it remained a part of the tradition throughout the centuries. ${ }^{30}$

That being said, the plight of the early community remained precarious, and eventually the following verse was revealed:

Permission to fight back is hereby granted to those being fought, for they have been wronged. And God is truly Most Capable of helping them prevail. They are those who have been expelled from their homes for no reason other than proclaiming: 'Our Lord is God.' Had God not repelled the aggression of some people by means of others, destruction would have surely claimed monasteries, churches, synagogues, and mosques in which God's name is often mentioned. God will certainly help those who stand up for Him. God is truly All-Powerful, Almighty. ${ }^{31}(22: 39-40)$

These verses have been understood traditionally as the first to allow for the use of force by believers, with scholars generally attributing them to either the time of the Hijra (622) or to the beginnings of the community in Medina. ${ }^{32}$ Mustansir Mir points out how, in fact, the reader is not told "who gave the permission or what is being permitted" while acknowledging that the context of the surah would indicate the granting of permission to fight in self-defense. He translates verse 39 in a way that does not specify that permission is being given to fight: "Permission is given to those against whom war is being waged, for they have been wronged; and God is fully capable of coming to their aid". The fact that the word "fighting" is not applied explicitly to the actions of those being persecuted (although many translators insert it, as is the case with Khattab above) suggests a hesitancy within the Qur'an about allowing such action. This is further underlined by the absence of any explicit reference to God as the one permitting the believers to take up arms, which is perhaps "a subtle way of saying that God does not wish to be associated with the granting of the permission". Even the grammatical structure of the passage contributes to this impression, 
as "the use of the passive voice in the verse ['Permission is hereby granted'] heightens yet further the mood of reluctance in giving the permission to fight". Mir concludes by noting how "The net effect of the construction "Permission is given" ... and of the absence of specification about the giver of the permission and the content of the permission is to suggest that war has been imposed on Muslims, who are now left with no choice but to fight back". ${ }^{33}$ Such fighting is an unfortunate aspect of human existence, whose origin can be found in humanity's refusal to live in accord with divine guidance. Consequently, it may sometimes be necessary (and indeed just) to fight in defense of victims and to end oppression. $^{34}$

Clearly, it is the suffering of "those being fought" which prompts the granting of permission to fight. In identifying those to whom permission has been given in this way, the Qur'an would appear to be making a general statement acknowledging the right of all victims (and not only Muslims) to defend themselves through recourse to the use of force ${ }^{35}$ At the very least, the text reveals an awareness of the need to defend the other "People of the Book" from religious persecution. Here, the Qur'an is addressing a situation that goes beyond difference in belief. People are being expelled from their homes, deprived of their property, reduced to penury, and treated with hostility and violence: "In other words, it is not merely the negative attitude toward religion per se that sanctions the use of force; it is the hostility to which it leads that makes it a prior moral offense and that requires a response with force". ${ }^{36}$ As has been already noted, the Qur'an displays acute sensitivity toward those who are oppressed and maltreated, and this concern extends beyond the boundary of the Muslim community. Confronted with the sight of obvious oppression, believers are exhorted not only to defend themselves, but to come to the aid of the defenseless (4:75). Esack writes, "Given the Qur'an's own option for 'the people' in general and for the oppressed in particular, in a context of oppression the highest form of righteousness is praxis in the service of the wronged and the exploited". ${ }^{37}$

However, it also becomes clear that, based upon the evidence found in the Qur'an, the transition from patient endurance to forceful defense was not an easy one, and it appears as if at least some members of the community were reluctant to take up arms: "Fighting has been made obligatory upon you, though you dislike it. Perhaps you dislike something that is good for you, and like something that is bad for you. God knows and you do not know ... For persecution is far worse than killing. And they will not stop fighting you until they turn you away from your faith-if they can" (2:216-17) ${ }^{38}$ Again, the passage is reflective of a situation in which the followers of Muhammad are facing an aggressive foe who will not relent. The Arabic word, fitnah, translated here as "persecution", can also mean "oppression" "strife" (usually indicating civil disorder), "disorder", "a time of trial or tribulation", "sedition", "tumult", or "temptation to evil". Asad prefers to render fitnah as "temptation to evil"; by doing so, he wishes to draw out how the Qur'an's message here is not solely focused on the community's enemies, but is, at the same time, a warning to the believers themselves to avoid falling into the same patterns of behavior they are suffering at the hands of their oppressors: "the idea being that it is not merely the deliberate deniers of spiritual truths who are exposed to such a temptation, but that also people who are otherwise righteous may fall prey to it unless they remain always, and consciously, on their guard against anything that might lead them astray from the right course". Understood in this way, the admonition that persecution is worse than killing stands as a reminder to the believers that, when fighting their enemies, they must remain constantly on guard against the temptation to become persecutors themselves. Michael Bonner makes a similar point, raising the possibility that the resort to war may actually be a form of temptation. ${ }^{39}$ The Qur'an itself contains an awareness of the dangers of escalating violence because, in the same surah, the exhortation to fight is accompanied by language which seeks to prevent fighting from spinning out of control:

Fight in the cause of God only against those who wage war against you, but do not exceed the limits. God does not like transgressors. Kill them wherever 
you come upon them and drive them out of the places from which they have driven you out. For persecution (fitnah) is far worse than killing. And do not fight them at the Sacred Mosque unless they attack you there. If they do so, then fight them-that is the reward of the disbelievers. But if they cease, then surely God is All-Forgiving, Most Merciful. Fight against them until there is no more persecution and your devotion will be to God alone. If they stop persecuting you, let there be no hostility except against the aggressors. (2:190-93)

I quote this passage at length because it is a wonderfully balanced summary of much of what the Qur'an has to say about the justification for and practice of fighting. The believers are permitted to defend themselves, but they are prohibited from being aggressors. Unless they are attacked by their persecutors, they are meant to avoid combat near the Kaba as well as during the sacred months in which war was forbidden according to pre-Islamic tradition. Retaliation in war is to be proportionate to the violence inflicted by the enemy. If their opponents cease their hostilities, the believers are to desist as well. The overall justification for this response on the part of the Muslim community is the conviction that "persecution is far worse than killing". Therefore, the believers are to fight "until there is no more persecution and your devotion will be to God alone".

The focus of this essay is on the Qur'an's attitude toward the use of violence in the service of alleviating the plight of the persecuted, wronged, and powerless; it is not a detailed study of all the verses dealing with fighting and war. However, in order to present the diversity of views regarding the employment of force, and to avoid the charge of having avoided some of the Qur'an's more controversial passages, something needs to be said about the "sword" verse from surah 9.40

"But once the sacred months have passed, kill the polytheists who violated their treaties wherever you come upon them, capture them, besiege them, and lie in wait for them on every way. But if they repent, perform prayers, and pay alms-tax, then set them free. Indeed, God is All-Forgiving, Most Merciful" (9:5). A second, similar verse is believed by some to be aimed at People of the Book: "Fight those who do not believe in God or the Last Day, nor comply with what God and His Messenger have forbidden, nor embrace the religion of truth from among those who were given the Scripture, until they pay the tax willingly submitting, fully humbled" (9:29). These verses have been the object of extensive commentary and the source of much controversy. Most of the controversy revolves around the question as to whether these two verses abrogate earlier verses that counsel greater restraint in responding to enemies. Much depends then on the interpreter's attitude toward the principle of abrogation, and whether the principle is applicable in this case. As an illustration of the some of the consequences that can follow from the acceptance of abrogation with regard to 9:5 and 9:29, those who argue in favor of abrogation say that the verses supersede two other important verses which advocate a less aggressive stance. Surah 8:61 exhorts believers to incline to peace if their enemies do likewise, trusting that God will sustain them even if their foes are insincere. Likewise, Surah 2:190-95 warns against aggressive behavior, insists upon proportionate response to attack, and cautions Muslims that if the enemy desists, then they must do the same. If then, the message of 9:5 and 9:29 is taken to be the final word with regard to the use of force, these earlier verses can be more easily ignored. However, there are well-regarded interpreters who do not agree that these verses abrogate previous statements about fighting, and who further argue that the meaning of verses does not violate the fundamental principles of non-aggression and self-defense present in the Qur'an. ${ }^{41}$ Rather than getting bogged down in arguments about which verses abrogate others, these scholars insist that the Qur'an must be read holistically, and that specific verses are to be understood in the context in which they arise and in relationship to similar verses in the text. From this hermeneutical perspective, it can then be maintained that, on the question of the use of force, it is the message of restraint that is most characteristic of the Qur'an as a whole.

For example, commenting on 9:5 and 9:29, Asad writes: "every verse in the Qur'an must be read and interpreted against the background of the Qur'an as a whole" and "In 
accordance with the fundamental principle ... that all of its (the Qur'an's) statements and ordinances are mutually complementary and cannot, therefore, be correctly understood unless they are considered as parts of one integral whole, this verse, too, must be read in the context of the clear-cut Qur'anic rule that war is permitted only in self-defense". To read these verses holistically would mean to consider them in light of other relevant and fundamental Qur'anic ordinances: that forcible conversion of unbelievers is prohibited (2:256); that unprovoked aggression is forbidden (2:190); that the believers are only justified in responding to the aggression committed by their foes in a proportionate manner (4:91); and that, if the enemy should cease hostilities, Muslims must do the same. ${ }^{42}$ Muhammad Abdel Haleem places 9:5 in its specific context in order to argue against its being used as a general rule: "The main clause of the sentence "kill the polytheists" is singled out by some Western scholars to represent the Islamic attitude to war; even some Muslims take this view and allege that this verse abrogated other verses on war. This is pure fantasy, isolating and decontextualizing a small part of a sentence". Asma Afsaruddin concurs:

Contemporary polemical literature that discusses Qur'an 9:5-whether produced by Islamist militants or some Western orientalist scholars-invariably asserts a mythical scholarly consensus on the abrogating status of the so-called sword verse, whereby numerous Qur'anic verses that call upon Muslims to establish kind and respectful relations with peaceful non-Muslims would be nullified. A survey of some of the most influential Qur'an commentaries of the premodern period easily disproves this assertion.

Haleem explains how, in context of 9:1-15, the verse is an example of the community of believers acting in self-defense against an enemy determined to force them to abandon their faith. The polytheists are not being fought because they are polytheists, but because they have repeatedly broken their treaties with Muslims, aided others against Muslims, attacked them, barred others from becoming Muslim, and expelled Muslims from their homes and places of worship. As Haleem makes clear, verse 7 cautions the believers that they are to honor treaties with polytheists who have not broken their agreements or who wish to live in peace with Muslims. ${ }^{43}$ Verse 9:29 may be understood similarly; in fact, some scholars would argue that it was originally directed at polytheists, and that an earlier version may not have even included a reference to the People of the Book. The translation of 9:29 by Mustafa Khattab (cited above) certainly gives the impression that the passage is directed at polytheists (and not at Christians and Jews), and, in his commentary on the passage, he states explicitly that it refers to pagans who have violated their treaties with Muslims. This would in fact help to explain the oddity of referring to Jews and Christians as people who do not believe in God or the Last Day, since these beliefs are central to both traditions. ${ }^{44}$ Another possible reading of the verse is that the People of the Book mentioned here exhibits the same hostility toward the Muslim community as the polytheists mentioned in 9:5. This is the view of Asad, who argues that those referred to were aggressors who were harassing Muslims. He argues that their refusal to forbid what "God and His Apostle have forbidden" is actually a reference to their unprovoked aggression, since not only Muhammad but the entire line of apostles had forbidden such violent actions. These acts of aggression are taken as evidence that these are false Christians and Jews, who may therefore be fought against, since "they deny their own professed beliefs by committing aggression against the followers of the Qur'an" ${ }^{45}$ In the view of many contemporary interpreters, then, verses 9:5 and 9:29 are not manifestos supporting conquest and forced conversion to Islam, but rather directions given for very specific circumstances in which the early community takes up arms in defense against those who have betrayed and attacked them. They can, therefore, be read as falling within the more general Qur'anic rubric which limits the use of force to self-defense or to those circumstances where there exists a moral obligation to act on behalf of the oppressed.

Whether read diachronically or synchronically, there is no question that the Qur'an presents a range of views with regard to the use of force in defense of victims-whether 
those victims are the defenseless, the oppressed, God's prophets and messengers, those persecuted for their faith, or the fledgling community itself. At times, the Qur'an advises patience in the face of persecution, while other parts of the text gives permission to fight against those who attack the community. Other verses reflect a reluctance on the part of at least some in the community to resort to violence; these are matched by verses that encourage the reluctant to join the battle on behalf of the persecuted and in the interest of self-defense. In nearly all instances, the believers are cautioned to employ restraint when engaging in fighting. Given this range of attitudes within the text, it can be very tempting to fall into the trap of trying to extract the doctrine of the Qur'an concerning the use of force by taking verses out of context, selecting only those which support the interpreter's position, or selectively employing the principle of abrogation in order to arrive at one's desired result. This citing and juxtaposing of alleged proof texts consumes a great deal of time and energy on the part of all parties involved in these debates and is generally no more fruitful than the interminable quarrels that so often characterize similar debates among those who take the Bible as their sacred text. Adopting this approach reduces the Qur'an to a collection of sayings, ordinances, and exhortations to be drawn upon in order to defend one's position or to derive rules to apply to one's particular circumstances. In the process, the integrity and coherence of the text as a whole is called into question. While there is no simple solution to this problem, the Qur'an contains within itself a key to enable its readers to grasp an underlying unity amidst the multiplicity of surahs and verses. That key is the idea of taqwa. As such, understanding the meaning and role of taqwa can be immensely helpful in making sense of the disparate strands within the Qur'an which deal with the use of force.

\section{The Role of Taqwa}

"Perhaps the most important single term in the Qur'an" is how Fazlur Rahman describes taqwa ${ }^{46}$ For Toshihiko Izutsu, taqwa "must act as the determining motive of all conduct of the religious man, nay rather it must determine the whole of human existence". It is the "most fundamental motif" of Islam, "that underlies all its aspects and determines its basic mood". Along with thankfulness, taqwa is considered to be the proper reaction to God's revelation. ${ }^{47}$

The term is variously translated as piety, mindfulness of God, fear of God, Godliness, reverence, and Godwary. For purposes of this essay, I follow Muhammad Asad and render the term as "God-consciousness". Part of the reason for this is that a translation such as God-consciousness (or mindfulness of God) avoids both the danger of limiting the term to religious ritual or prayer, as well as avoiding the misunderstandings involved when rendering taqwa as fear of God. While fear as a human emotion (in the sense of being afraid of something or someone) is not entirely alien to this idea, the fundamental sense of taqwa is an awareness of always living in the presence of the mystery of mercy and awe that is referred to by the word Allah/God. Izutsu captures this well:

Of course it should be kept in mind that this emotion of 'fear' meant in this case far more than being afraid of punishment ... [The] deep ethico-religious value of the fear of God, the Lord of the Day of Judgment, is largely due to the fact that it cannot but arouse in the mind of the believer a clear consciousness of the tremendous seriousness of life and thus incite him to moral earnestness and responsibility. ${ }^{48}$

Rahman comments that while translations such as "fear of God" and "piety" are not wrong, they can be misleading. Explaining how the root of the word means "to guard or protect against something", he adds that taqwa can be understood as protecting oneself "against the harmful or evil consequences of one's conduct". He concludes by saying that:

If by "fear of God one means fear of the consequences of one's actions-whether in this world or the next (fear of punishment of the Last Day)-one is absolutely right. In other words, it is the fear that comes from an acute sense of responsibility, 
here and in the hereafter, and not the fear of a wolf or of an uncanny tyrant, for the God of the Qur'an has unbounded mercy-although He also wields dire punishment, both in this world and in the hereafter. ${ }^{49}$

Both Izutsu and Rahman emphasize the prominence of the eschatological tone that often accompanies references to taqwa in the Qur'an. There are at least fifty instances in which taqwa is associated with the Last Day, resurrection, or the afterlife. Yet, as both authors insist, those who possess taqwa are not motivated by the desire to avoid punishment from God after death. They are spared punishment in the next world because they are persons who, throughout their lives, have cultivated taqwa in themselves as a positive value, not as a shield against hellfire. After warning of hellfire, Surah 92 concludes with the following praise of the those who embody taqwa: "For distant from it [hellfire] shall remain he who is truly conscious of God: he that spends his possessions on others so that he might grow in purity-not as payment for favours received, but only out of a longing for the countenance of his Sustainer, the All-Highest: and such, indeed, in time shall be well-pleased (92:17-21). ${ }^{50}$ In light of this passage, it is easy to understand why Rahman attributes such importance to taqwa:

[The] fully integrated and whole personality of man, the kind of 'stability' which is formed after all the positive elements are drawn in. Considering all the verses in the Qur'an related to this concept, perhaps the best way to define taqwa is to say that, whereas action belongs to man, real and effective judgment upon that action, as well as the standard whereby that action is to be judged, lie outside of him ... When a man or a society is fully conscious of this while conducting himself or itself, he or it has true taqwa. ${ }^{51}$

The emphasis here is on integration and wholeness rather than on the capacity to follow rules. Taqwa does not mean that one is constantly thinking about God when considering how to act, nor is it mainly a matter of pausing in the midst of particular situations to ask oneself what the Qur'an or the Prophet have to say about what to do in such circumstances. God-consciousness is a deep, internalized, and implicit awareness of God that, in a fully integrated and actualized person accompanies all that he or she does, and functions as a form of guidance. It is immanent in its actualization and transcendent in its source.

A splendid and frequently cited description of taqwa occurs in Surah 2:177:

True piety does not consist in turning your faces towards the east or the westbut truly pious is he who believes in God and the Last Day, and the angels, and revelation, and the prophets; and spends his substance-however much he himself may cherish it-upon his near of kin, and the orphans, and the needy, and the wayfarer, and the beggars, and for the freeing of human beings from bondage; and is constant in prayer, and renders the purifying dues; and [truly pious are] they who keep their promises whenever they promise, and are patient in misfortune and hardship and in time of peril: it is they who have proved themselves true, and it is they, they who are conscious of God.

This passage beautifully summarizes the meaning of taqwa as it manifests itself in and through human persons. Striking also is the explicit connection that is made between taqwa, attentiveness to the indigent, liberation from bondage, and the counsel of patience in the midst of hardship and peril. Surah 3:133-35 is equally expressive of how taqwa shines forth in the lives of those who are devoted to making God's desires their own:

And vie with one another to attain to your Sustainer's forgiveness and to a paradise as vast as the heavens and the earth, which has been readied for the God-conscious who spend in His way in time of plenty and in time of hardship, and hold in check their anger, and pardon their fellow-men because God loves the doers of good; and who when they have committed a shameful deed or have [otherwise] sinned against themselves, remember God and pray that their sins be 
forgiven-for who but God could forgive sins?-and do not knowingly persist in doing whatever [wrong] they may have done.

Taqwa does not confer perfection, but an abiding awareness that enables persons to understand the ways in which they have sinned and to then seek forgiveness. Especially noteworthy in this passage is the observation that, in falling away from taqwa, people are departing from their true selves as oriented toward God. In other words, we are most ourselves when our thoughts and deeds have their origin in God-consciousness. Taqwa is the basis of human authenticity, and as such, it is cited as the source of happiness, nobility, human fraternity, justice, and the ability to discern what is true and false. ${ }^{52}$

In order to understand the relationship between God-consciousness and the use of force, it is important to have a sense of the Arabian context within which Islam arose. In his writings on the Qur'an, Izutsu underscores the intensely competitive, rivalry-ridden nature of pre-Islamic Arabian society. He describes how this period (referred to as jahiliyah or Time of Ignorance) was not characterized primarily by "ignorance" but by:

[The] keenest sense of tribal honor, the unyielding spirit of rivalry and arrogance, and all the rough and rude practices coming from an extremely passionate temper ... notoriously passionate people who may be moved to any extremes on the smallest provocation ... From the standpoint of Islam, the jahiliyah was a blind, savage passion ... And it was this dark, blind passion that had inspired endless blood feuds, and caused countless miseries and disasters in the history of the pre-Islamic Arabs. ${ }^{53}$

According to Tamin Ansary, "In this part of the world, small-scale warfare was endemic ... Add the Arabian tradition of blood feuds lasting for generations, add also the tapestry of fragile tribal alliances that marked the peninsula at this time, and you have a world seething with constant, ubiquitous violence" ${ }^{54}$ Clearly, what is being described is a never-ending cycle of ever-increasing, passion-driven violence, devoid of restraining influences. Izutsu also points out how the spirit of jahiliyah is not restricted to a particular historical period (although this is how later Islamic tradition came to view it); rather, in its original meaning, it was intended to describe a danger inherent in all human relationships, i.e., the danger of an escalating violence capable of engulfing and ultimately destroying a society. ${ }^{55}$ This may help to explain why the Qur'an justifies the use of force against an aggressive, unrelenting enemy when it states that "strife is worse than slaying" (2:191). ${ }^{56}$ This was the societal context in which the Qur'anic understanding of taqwa made its appearance. Surah 49:13 reveals the intended transformation to be wrought by the new faith: "Behold, we have created you all out of male and female, and have made you into nations and tribes, so that you might come to know one another. Verily, the noblest of you in the sight of God is the one who is most deeply conscious of Him". In this passage, the differentiation among peoples and tribes exists as an opportunity for a mutually enriching encounter rather than as a source of unending strife and conflict. The most radical change announced here is in the meaning of what it means to be noble (karim): "The combination of nobility and reverence marks a remarkable transition from the attitudes of pre-Islamic Arabia in which reverence (taqwa) and nobility were considered polar opposites" ${ }^{57}$ To be considered noble in Arabia in pre-Islamic times meant, first of all, to be of noble lineage. In terms of personal characteristics, it meant being generous (an aspect of the idea that was retained in Islam), but also being easily provoked into the use of retaliatory violence in order to settle scores and to uphold one's honor or the honor of one's kin. With the coming of Islam, however, what now counts as nobility is the possession of God-consciousness. Izutsu observes: "We can hardly overemphasize the revolutionary nature of this attempt to re-evaluate semantically an old moral word. Already in the day of Jahiliyah karim was one of the highest value-words, meaning roughly both nobility of birth and generosity. But no one before Islam could have thought of defining 'nobility' in terms of 'fear of God' [taqwa]". 58 
It remains to consider the implications of taqwa with regard to the possible use of force. Given the pre-Islamic context just described, it should not come as a surprise that God-consciousness is frequently associated with a counsel of restraint when confronted with a temptation to resort to violence. ${ }^{59}$ In Surah 22:39-40, the community of believers was given permission to resort to force when under attack. However, this permission is nearly always qualified by multiple passages which associate God-consciousness with forbearance in the face of hardship. ${ }^{60}$ Surah 2:177 has already been cited above; there, Godconsciousness is identified with those who "are patient in misfortune and hardship and in time of peril". Believers may respond in kind to aggression, but "to bear yourselves with patience is indeed far better for you, since God is with those who are patient in adversity ... for God is with those who are conscious of Him and are doers of good withal" (16:126, 128). In 2:91, Muslims are told that they may fight because "oppression [or strife] is worse than killing"; however, they are warned in the preceding verse that they are only to use force when attacked, and that God does not love aggressors. The brake against aggression is then directly linked to the presence of taqwa: "Thus if anyone commits aggression against you, attack him just as he has attacked you-but remain conscious of God, and know that God is with those who are conscious of Him" (2:194). This exhortation should not be construed as telling the believers that God approves of whatever they do in war; rather, it serves as a warning to them that, without God-consciousness, they are liable to bring destruction on themselves through excessive zeal for retaliation and revenge. The prophet Hud addresses just such a warning to his people, who were renowned for their cruelty and their unrestrained violence in war. Within eight brief verses (26:124-32), the people of Ad are exhorted to be conscious of God four times; without the presence of taqwa, their violence will know no limits and they will continue to sin against others as well as against themselves. For Asad, this exemplifies “a Qur'anic prohibition, valid for all times, of all unnecessary cruelty in warfare, coupled with the positive, clearly implied injunction to subordinate every act of war-as well as the decision to wage war as such-to moral considerations and restraints". ${ }^{61}$ It is taqwa that serves as the source of such moral consideration and restraint. Taqwa always functions as a reminder that, in cases where it may be necessary to resort to violence in self-defense, the response is to be strictly proportional to the act of aggression. ${ }^{62}$ This applies in exactly the same way to the so-called "sword verse" where it is made clear that treaties are to be honored and that violence is to end as soon as the aggressors relent. Here too, all the qualifications introduced with the goal of preventing an escalation of violence are prefaced with the observation that "verily, God loves those who are conscious of Him (9:4), as well as repeated reminders that God is "much-forgiving" and a "dispenser of grace". Transformed by this grace, it is characteristic of the God-conscious that "they hold in check their anger and pardon their fellow-men because God loves the doers of good" (3:134). In instance after instance in the Qur'an, warnings about the use of force and exhortations toward restraint are accompanied by invocations of taqwa. God-consciousness must always be present, both when contemplating the use of force and in the midst of fighting in order to prevent the escalation of violence.

It would be a misunderstanding, however, to equate God-consciousness only with hesitancy regarding the use of force. As noted earlier, there existed among some members of the early Muslim community strong reservations about the resort to violence. Reasons for this hesitancy varied: at times, it was considered to be an inappropriate response to a particular situation; at other times, it may have been a matter of principle; and in many instances, the reluctance arose from an unwillingness to take up arms against members of their kin. In these circumstances, an appeal to taqwa formed the basis of an exhortation to the doubtful to take up arms in the interests of religious freedom and defending the innocent. Recall 22:39, in which "permission is given" to respond to aggressors and to protect churches, mosques, and synagogues from being destroyed. This verse is preceded by seven verses which clarify that the goal of all worship is the cultivation of God-consciousness in the believer. It is difficult to believe that this is a coincidence; it makes far more sense to imagine that the reason for this sequence is that, even when the use of force can be justified, 
it must always have its source in a profound sense of ones responsibility before God to protect the community from destruction and to preserve the freedom to worship, and not in the human desire for retaliation or vengeance. In cases such as this, God-consciousness is not an incitement to violence for those already predisposed toward retaliation, but an awareness of the sad reality that, if the innocent are to be protected, there may be times when the use of force is justified.

Similarly, when the community's very existence is in question, and enemies are determined to eradicate worship of the one God, all are summoned to fight: "Fighting is ordained for you, even though it is hateful to you ... since oppression is more awesome than killing. [Your enemies] will not cease to fight against you till they have turned you away from your faith, if they can" (2:16-17). In this situation, the eschatological dimension of taqwa is invoked in a way that relativizes the value of life in this world in comparison with the life to come: "Unto those who are bent on denying the truth, the life of this world [alone] seems goodly; hence they scoff at those who have attained to faith: but they who are conscious of God shall be above them on Resurrection Day" (2:12). This judgment is not rooted in any sense of otherworldliness or denial of the goodness of earthly life, but in the realization that God-consciousness places life in an eschatological context, wherein risking one's life in order to fight against oppression is a higher calling and more in accord with God's desires than self-preservation. Surah 4:75-77 makes this explicit:

And how could you refuse to fight in the cause of God and of the utterly helpless men and women and children who are crying, "O Our Sustainer! Lead us forth [to freedom] out of this land whose people are oppressors ... Art thou not aware of those who have been told, "Curb your hands, and be constant in prayer, and render the purifying dues"? But as soon as fighting [in God's cause] is ordained for them, lo, some of them stand in awe of men as one should stand in awe of God ... and say, "O Our Sustainer! Why hast thou ordained fighting for us? If only Thou hadst granted us a delay for a little while!" Say; "Brief is the enjoyment of this world, whereas the life to come is the best for all who are conscious of God...

For the most part, God-consciousness serves as a restraining influence on human violence, given the propensity of violence to escalate and to claim for itself the name of justice, when it is in fact often nothing more than an expression of anger, rivalry, and the desire for vengeance. Nevertheless, Muslims are not Quakers and, according to the Qur'an, there are times when it is necessary to employ force in order to come to the aid of victims. God-consciousness plays a role here as well, balancing the need to limit violence against the moral responsibility to act to alleviate oppression.

Hopefully it has been become clear by this point that taqwa is not a matter of applying rules to situations, or even of internalizing a set of ordinances. Taqwa works at a deeper level, where persons are open to allowing God's desires to become their own. In other words, taqwa is the goal of ongoing conversion of mind and heart. This is evident from several passages in the Qur'an, particularly in 5:2 and 5:8: "And never let your hatred of people who would bar you from the Inviolable House of Worship lead you into the sin of aggression: but rather help one another in furthering virtue and God-consciousness, and do not help one another in furthering evil and enmity; and remain conscious of God: for behold, God is severe in retribution" (5:2) and "[Never] let hatred of anyone lead you into the sin of deviating from justice. Be just: this is closest to being God-conscious. And remain conscious of God: verily, God is aware of all that you do" (5:8). An important example of the transformative influence of taqwa is recorded in Surah 48, which reflects the circumstances surrounding the Truce of Hudaybiyyah in 628. This truce established peace between the Muslim community in Medina and the still predominantly pagan city of Mecca. The treaty that produced the truce was controversial and created division among the Muslims, some of whom thought that Muhammad and his associates had been far too yielding and conciliatory. Verse 26 describes the intransigence of the Meccans, but then goes on to indicate the source of the Muslim negotiators' willingness to compromise: "Whereas 
they who are bent on denying the truth harbored a stubborn disdain in their hearts-the stubborn disdain [born] of ignorance-God bestowed from on high His [gift of] inner peace upon His Apostle and the believers, and bound them to the spirit of God-consciousness: for they were most worthy of this [divine gift], and deserved it well". Muhammad and his companions do not come to the meeting with a list of demands or even with an agreed upon strategy; gifted with God-consciousness, they are able to set aside their pride, their anger, and their desire to win, in order to pursue peace.

This would seem to be a fitting image with which to conclude this essay, i.e., an image of the Prophet and his followers defying expectations through the grace of Godconsciousness. It is fitting as well because it exemplifies how taqwa operates, not at the level of law and command, but by means of the transformation of persons. In many ways, taqwa functions within the Qur'an, much like the role of love in St. Augustine's famous phrase, "Love, and do as you will". In the context of the sermon in which it is given, the similarity in meaning is striking:

This is what I insist upon: human actions can only be understood by their root in love. All kinds of actions might appear good without proceeding from the root of love. Remember, thorns also have flowers: some actions seem truly savage but are done for the sake of discipline motivated by love. Once and for all, I give you this one short command: love, and do what you will. If you hold your peace, hold your peace out of love. If you cry out, cry out in love. If you correct someone, correct them out of love. If you spare them, spare them out of love. Let the root of love be in you: nothing can spring from it but good ... 63

One could easily substitute "taqwa" for "love" in this excerpt with little or no change in meaning. Those familiar with Augustine know that his views were quite compatible with the Qur'anic belief that terrible harm would befall the innocent, and that churches, mosques, and synagogues would be destroyed unless "God had not enabled people to defend themselves against one another" (22:40). For Augustine, a Christian general will engage in war when necessary, but without being in any way motivated by hatred or a desire for revenge. Likewise, the early Muslim community may take up arms in self-defense and to remove oppression as long as the believers possess hearts and minds illuminated by God-consciousness. It is obvious that, in both cases, the decision to use force is taken reluctantly and with every intention of restoring peace and protecting the defenseless.

That being said, the Qur'an has no illusions about the role of God-consciousness. It is not magic. It does not confer infallibility on those who possess it, and sometimes it may be claimed by those who do not possess it in order to justify their aggressive schemes. The Qur'an makes clear that God-consciousness is a gift, but one that can and must be cultivated by prayer, fasting, and charity. ${ }^{64}$ The kind of conversion required to allow Godconscious to take hold of one's heart and mind is a life-long process, involving ongoing repentance and forgiveness. ${ }^{65}$ Some may find the idea of taqwa too vague and ineffectual to have any relevance with regard to questions about the use of force. However, this is to forget that persons conduct wars and engage in fighting. The message of the Qur'an is that persons possessed of taqwa will be least likely to resort to such actions, precisely because their hearts and minds reflect the reality of a God who is merciful and compassionate. The Qur'an affirms that there is such a thing as human authenticity, and that it depends on actualizing and deepening one's relationship with God. It is in this sense that it is possible to understand taqwa as the single most important term in the Qur'an, since all the ordinances, exhortations, commands, stories, and sayings within the text are intended to enable the reader to grow in God-consciousness and must, therefore, be referred back to God-consciousness as their goal.

As an example of how taqwa has concrete implications with regard to questions about fighting, consider how, taking taqwa into consideration, the whole issue of abrogation is relativized and relegated to a position of secondary importance. In light of God-consciousness, those who would prioritize the "sword" verse in the name of abrogation would be intel- 
lectually dishonest if they ignored the strict qualifications on fighting imposed by taqwa both in Surah 9 and, in many instances, wherever the question of fighting arises in the Qur'an. Throughout the Qur'an, in those texts that allow or advocate the use of force, God-consciousness always acts as a moderating influence and, in those places where some members of the community may be reluctant to take up arms, it helps to move them to action in order to respond to oppression. Which verses came first, and which verses abrogate others no longer counts for much, since God-consciousness is always present as balance and restraint. It provides a flexible standard rooted in ongoing conversion; a standard that is capable of dealing with changing situations because those who possess it have allowed themselves to be transformed by God and have become most fully themselves, i.e., persons capable of reflecting the mercy and compassion of their Maker. It may be well to be reminded that the written text of the Qur'an is a series of marks on a page. These marks and the text they form "say" nothing apart from the human interpreter. Once this is understood, the key questions are no longer who can cite verses more accurately, or memorize bits of text, or apply rules taken out of context to justify their violence. Instead, the most important question concerns the human authenticity of the interpreter. Here, God-consciousness is key.

Funding: This research received no external funding.

Institutional Review Board Statement: Not applicable.

Informed Consent Statement: Not applicable.

Data Availability Statement: Not applicable.

Conflicts of Interest: The author declares no conflict of interest.

\section{Notes}

2:20, 83, 177, 184, 215, 220, 271, 273; 4:2, 6, 8-10, 36, 127; 9:60; 17:26, 34; 22:28; 30:38; 56:73; 68:24; 69:34; 70:25; 74:44; 76:8-9; 89:17-18; 90:13-16; 93:6-10; 107:1-7. See also (Esack 2006, pp. 97, 99, 102; Rahemtulla 2018; Rahman 2009).

(Khattab 2016). Unless otherwise noted, quotations of the Qur'an are taken from this translation.

(Asad 2003), 90:13 n. 7.(Ali 2012) 90:13 n. 6140.

$4 \quad$ Asad, 2:177 n. 146; 8:67 n. 72; 16:71 n. 80; Yusuf Ali, 2:177 n. 179; 8:67 n. 1234; (Nasr 2015), 16:71. See also Rahman, Major Themes, 48 .

Asad, 76:8 n. 10.

Yusuf Ali, 76:8 n. 5839; Asad 76:8 n. 11.

Among the places where almsgiving is mentioned are: $2: 43,83,110,177,277 ; 4: 77,162 ; 9: 5,11,18,71 ; 22: 41,78 ; 24: 37,56 ; 41: 7$; 58:13; 73:20; 98:5. See also Study Quran, 8:41; 59:7; Asad, 22:28 n. 41

Places where these practices are mentioned include: 6:137, 140, 151; 16:56-59; 17:31; 60:12; 70:11-14 and 81:8-9.

Asad, 6:137 n.123.

Study Quran, 81:8-9 n. 8, 9.

(Tottoli 2002).

(Esack 2006, pp. 102, 194-205).

Also 2:49-50; 7:137; 10:90-93; 17:103-104; 20: 46, 80; 26:15-17, 59-66; 28:5; 40:45.

(Esack 2006, pp. 98-99).

2:51-74; 5:24; 7:138-56; 20:85-97.

(Esack 2006, pp. 202-3).

(Donner 2010).

Also $3: 184 ; 6: 10 ; 8: 30 ; 13: 32 ; 21: 41 ; 35: 4 ; 38: 12 ; 40: 5 ; 60: 1-2$.

$2: 155-57,214,286 ; 3: 195 ; 5: 11 ; 12: 110 ; 16: 41,110 ; 18: 9-26 ; 22: 58,60 ; 33: 48 ; 59: 8 ; 60: 1-2,9$.

$2: 30,60,72,205 ; 5: 64 ; 8: 25,73 ; 13: 25 ; 26: 183 ; 27: 48-49 ; 28: 4,77,83 ; 30: 41 ; 38: 28 ; 47: 22 ; 50: 25 ; 59: 14$.

(Arkoun 2003).

Arkoun, "Violence," 433. Arkoun places "violence" in quotes to indicate the already noted point that the Qur'an does not a single word that could be translated as such, and consequently it does not treat violence as a separate theme. 
For descriptions of the traditional view see: (Afsaruddin 2013).

(Firestone 1999; Bonner 2008). For criticism of this view as well as that of abrogation: Afsaruddin, "Islam and Violence," 154-59; (Afsaruddin 2010; Dagli 1809); Firestone, Jihad, 49-51; (Haleem 1999; Musa 2012; Sachedina 1990). For a synchronic treatment of the relevant verses on the use of force: Firestone, Jihad, 67-91.

Dagli, "Conquest and Conversion,"1806. See also Abu-Nimer and Badawi, "Alternatives to War and Violence," 160; Afsaruddin, "Islam and Violence," 147-48; Afsaruddin, "Recovering the Early Semantic Purview of Jihad," 40; Afsaruddin, Striving in the Path of God, 1-2, 268-69; Bonner, Jihad in Islamic History, 21-22; Firestone, Jihad, 16-17; Haleem, Understanding the Qur'an, 64-68; (Landau-Tasseron 2003, pp. 35-42); Musa, “Qur'anically-Based Articulation of 'Just War,'” 28-29; Sachedina, "The Development of Jihad," 37.

Abu-Nimer and Badawi, “Alternatives to War and Violence," 160; Afsaruddin, “Islam and Violence," 148, 153-54, 159; Afsaruddin, "Recovering the Early Semantic Purview of Jihad," 41, 48-49, 57-58; Afsaruddin, Striving in the Path of God, 1-3; Dagli, "Conquest and Conversion," 1805; Firestone, Jihad, 15; Landau-Tasseron, "Jihad," 42; Sachedina, "The Development of Jihad, 36, 38; (Sachedina 1996; Johnson 1997). As examples of the wide range of perspectives on these matters, consider how the titles of at least two significant studies of jihad and warfare in Islam refer to the term "holy war"-Firestone, Jihad: The Origins of Holy War in Islam and James Turner Johnson, The Holy War Idea in Western and Islamic Traditions. To be fair, both authors acknowledge the problems involved in applying this term to jihad and warfare in Islam (Firestone, 15; Turner Johnson, 25-26). Contrast this with the categorical rejection of such usage by other scholars, such as Afsaruddin ("[The] military jihad in the Qur'an itself is most categorically not holy war that is fought to impose or even propagate Islam ..., " Path, 280; "At the semantic level, the facile translation of jihad into English as holy war, as is common in some scholarly and nonscholarly discourses, constitutes a major misrepresentation and misunderstanding of the term's Qur'anic usage," Jihad, 41) and Haleem ("[Jihad] does not mean 'Holy War.' 'Holy War' does not exist as a term in Arabic, and its translation into Arabic sounds quite alien," 64). Similarly, Landau-Tasseron writes of "the sacredness of Islamic warfare," explaining how, even though both jihad and the more general term for warfare (harb) are "disparate concepts ... both are endowed with sanctity" (42); while Afsaruddin maintains that "Violence is never redemptive in the Qur'an nor is it sacred ... " (Islam and Violence, 163). As already mentioned, a contributing factor to confusion in these matters has to do with the problematic use of the term "religion." More specifically, the "myth of religious violence," would have us believe that the use of force on behalf of "religion" is especially dangerous and fanatical compared to the "secular" violence of the state. See (Cavanaugh 2009, 2018).

Afsaruddin, "Islam and Violence," 148; Afsaruddin, "Recovering the Early Semantic Purview of Jihad," 42-43; Afsaruddin, Striving in the Path of God, 34; Dagli, "Conquest and Conversion," 1806; Firestone, Jihad, 54; Haleem, Understanding the Qur'an, 63; John Kelsay, "jihad" "nonviolence," in (Bowering 2013); Landau-Tasseron, “Jihad," 40; (Tibi 1996).

Also 2:109; 16:110, 126-27; 25:75; 29:59; 33:48; 39:10; 47:31.

Asad adds by way of commentary: "In other words, successful struggle against tyranny ... often tends to degenerate into a similarly tyrannical attitude towards the erstwhile oppressors. Hence, most of the classical commentators ... stress the absolute prohibition of 'going beyond what is right' when defending oneself against tyranny and oppression" (42:40n.40). Sachedina, "Justification," 140.

Firestone, Jihad, 52-53; Asad, 16:125-27 n.149-50; Abu-Nimer and Badawi, “Alternatives to War and Violence," 158-63; Ahmed Afzaal, "nonviolence," in (Bowering 2013, p. 396); Afsaruddin, "Islam and Violence," 148; "Recovering the Early Semantic Purview of Jihad," 50-51.

Also 22:60; 26:227.

Asad, 22:39 n.57; Study Quran, 22:39 n.39, 1807; Firestone, Jihad, 54; (Hashmi 1996).

(Mir 2008). Afsaruddin makes a similar point: "It should be noted that the Arabic uses the passive verb (yuqataluna; literally, "those who are fought against") instead of the active (yuqatiluna; literally "those who fight") in Qur'an 22:39 ... The passive verb yuqataluna in the verse therefore clearly refers to fighting back only after one has been attacked. Recourse to defensive fighting was established in these verses for Muslims not for the sake of propagating their religion but for the protection of their lives and property," (Afsaruddin, "Islam and Violence," 148; Striving in the Path of God, 42, pp. 271-72).

Afsaruddin, "Islam and Violence," 158; (Arkoun 1994, p. 58); Hashmi, "Interpreting the Islamic Ethics of War and Peace," 148, 151; Musa, "Qur'anically-Based Articulation of 'Just War,'” 32-35; Sachedina, "Justification," 124, 130, 133, 155; (Sizgorich 2013, p. 588).

Sachedina, "Justification," 126.

Esack, Qur'an, Liberation E Pluralism, 193. See also Afsaruddin, “Recovering," 44-45; Bonner, Jihad, 31; Musa, “Just War," 32, 35; Sachedina, "Justification," 129.

Firestone, Jihad, 67, 77-84; Afsaruddin, Striving, 34. Other references which appear to be directed against those who resisted the call to fight: $3: 156,167 ; 4: 75,77,95 ; 9: 38$.

Asad, 8:25 n.25; Bonner, Jihad, 27 n.17; Also, Afsaruddin, “Recovering," 44; Firestone, Jihad, 55, 58-59, 85-88, 160 n.65, 160-61 n.75; Sachedina, "Development of Jihad, 39; “Justification," 124-25, 131, 151-52. 


\section{References}

Abu-Nimer, Mohammad, and Jamal A. Badawi. 2011. Alternatives to War and Violence: An Islamic Perspective. In Peace Movements Worldwide: Players and Practices in Resistance to War. Edited by Marc Pilisuk and Michael N. Nagler. Santa Barbara: Praeger, p. 158 Afsaruddin, Asma. 2010. Recovering the Early Semantic Purview of Jihad and Martyrdom. In Crescent and Dove: Peace and Conflict Resolution in Islam. Edited by Qamar-ul Huda. Washington, DC: United States Institute of Peace Press, p. 48.

Afsaruddin, Asma. 2013. Striving in the Path of God: Jihad and Martyrdom in Islamic Thought. Oxford: Oxford University Press.

Afsaruddin, Asma. 2018. Islam and Violence: Debunking the Myths. In Does Religion Cause Violence? Edited by Scott Cowdell, Chris Fleming, Joel Hodge and Carly Osborn. New York: Bloomsbury Academic, p. 163.

Ali, Abdullah Yusuf, trans. 2012, The Holy Qur'an: Text, Translation and Commentary. New York: Tahrike Tarsile Qur'an.

Ansary, Tamin. 2009. Destiny Disrupted: A History of the World Through Islamic Eyes. New York: PublicAffairs, p. 29.

Arkoun, Mohammed. 1994. Rethinking Islam. Translated by Robert D. Lee. Boulder: Westview Press, p. 58.

Arkoun, M. Violence. 2003. Encylopaedia of the Qur'an, Volume Five Si-Z. Edited by Jane Dammen McAuliffe. Leiden: Brill, p. 432.

Asad, Muhammad, trans. 2003, The Message of the Qur'an. London: The Book Foundation.

Bonner, Michael. 2008. Jihad in Islamic History. Princeton: Princeton University Press, pp. 25-27.

Bowering, Gerhard, ed. 2013. The Princeton Encyclopedia of Islamic Political Thought. Princeton: Princeton University Press, p. 273.

Cavanaugh, William T. 2009. The Myth of Religious Violence. Oxford: Oxford University Press.

Cavanaugh, William T. 2018. Girard and the Myth of Religious Violence. In Does Religion Cause Violence? Edited by Scott Cowdell, Chris Fleming, Joel Hodge and Carly Osborn. New York: Bloomsbury Academic, pp. 7-24.

Dagli, Caner K. 1809. Conquest and Conversion, War and Peace in the Quran. In The Study Quran. New York: Harper Collins Press. 
Donner, Fred M. 2010. Muhammad and the Believers: At the Origins of Islam. Cambridge: The Belknap Press of Harvard University Press.

Esack, Farid. 2006. Qur'an, Liberation \& Pluralism. Oxford: Oneworld Publications.

Firestone, Reuven. 1999. Jihad: The Origins of Holy War in Islam. Oxford: Oxford University Press, pp. 50-65.

Haleem, Muhammad Abdel. 1999. Understanding the Qur'an: Themes and Style. London: I.B. Tauris, p. 67.

Hashmi, Sohail H. 1996. Interpreting the Islamic Ethics of War and Peace. In The Ethics of War and Peace. Edited by Terry Nardin. Princeton: Princeton University Press, p. 150.

Izutsu, Toshihiko. 2002. Ethico-Religious Concepts in the Qur'an. Montreal: McGill-Queen's University Press.

Johnson, James Turner. 1997. The Holy War Idea in Western and Islamic Traditions. University Park: The Pennsylvania State University Press.

Khattab, Mustafa, trans. 2016, The Clear Quran. Lombard: Book of Signs Foundation.

Landau-Tasseron, Ella. 2003. Jihad. In Encylopaedia of the Qur'an, Volume Three J-O. Edited by Jane Dammen McAuliffe. Leiden: Brill, pp. 35-42.

Mir, Mustansir. 2008. Understanding the Islamic Scripture. New York: Pearson Education Inc., pp. 164, 167-68.

Musa, Aisha Y. 2012. Towards a Qur'anically-Based Articulation of 'Just War. In Contemporary Approaches to the Qur'an and Sunnah. Edited by Mahmoud Ayoub. Washington, DC: The International Institute of Islamic Thought, pp. 33-34.

Nasr, Seyyed Hossein, ed. 2015. The Study Quran. New York: HarperCollins.

Rahemtulla, Shadaab. 2018. Qur'an of the Oppressed: Liberation Theology and Gender Justice in Islam. Oxford: Oxford University Press, pp. 10-52.

Rahman, Fazlur. 2009. Major Themes of the Qur'an. Chicago: The University of Chicago Press, pp. 38-40, 46-47, 50.

Sachedina, Abdulaziz. 1990. The Development of Jihad in Islamic Revelation and History. In Cross, Crescent, and Sword: The Justification and Limitation of War in Western and Islamic Tradition. Edited by James Turner Johnson and John Kelsay. New York: Greenwood Press, pp. 35-36, 43.

Sachedina, Abdulaziz. 1996. Justification for Violence in Islam. In War and Its Discontents: Pacifism and Quietism in the Abrahamic Traditions. Edited by J. Patout Burns. Washington, DC: Georgetown University Press, pp. 128-31.

Sizgorich, Thomas. 2013. Violence. In The Princeton Encyclopedia of Islamic Political Thought. Edited by Gerhard Bowering. Princeton: Princeton University Press, p. 588.

Tibi, Bassam. 1996. War and Peace in Islam. In The Ethics of War and Peace. Edited by Terry Nardin. Princeton: Princeton University Press, pp. 132-33.

Tottoli, Roberto. 2002. Biblical Prophets in the Qur'an and Muslim Literature. New York: Routledge, pp. ix, 4-7, 10. 